NASZA DERMATOLOGIA Online OUR DERMATOLOGY Online

Sowre of Support: Nil

Competing Interests: None declared

\section{MEDICAL EPONYMS LINKED TO NAILS}

\author{
Khalid Al Aboud
}

Pathology Department, Wake Forest University, Winston-Salem, NC, USA

Corresponding author: Dr. Khalid Al Aboud

amoa65@hotmail.com
The nails are affected by several dermatological and systemic diseases, and it is uncommon to find an isolated nail abnormalities.

However, there are some diseases, in which the nails are affected primarily and similarly there are syndromes in which the nails affection is one of its major components.

Some medical conditions in which there is a link to the nails are known eponymously (Tabl. I).

However not all „nails eponyms" are used commonly. For example, there are eponymous synonyms for nail-patella syndrome (NPS) [1]. NPS is defined by three major features: nail anomalies, skeletal anomalies and renal disease. It is also known as, Fong disease, Österreicher-Turner syndrome, or Turner-Kieser syndrome, nevertheless this syndrome is best known as nail-patella syndrome [22].

Fong disease is the eponym given after Edward Everett Fong, an American radiologist, born 1912, and who discovered the disease in 1946.

John W. Alden Turner was an American physician. His name was associated with NP, because of his description of two extensively affected families [23]. (The designation Turner syndrome, however, leads to confusion with the XO syndrome).Willibald Kieser, was, a German physician, whereas, Walther Österreicher, was an Austrian physician, born 1901.

In „nails eponyms", there are eponyms which refer to the same condition like Plummer-Vinson or Paterson-Kelly syndrome.

Lastly there are „,nails eponyms”, which may not survive more because of the improvement in our genetic understanding for the conditions they were named for.

For instance, pachyonychia congenital types are currently best known by the genetic defects rather than its earlier eponymous types Jadassohn-Lewandowsky syndrome and Jackson-Lawler syndrome.

\section{REFERENCES}

1. Al Aboud A: Al Aboud Separating, „Bart's” apart in dermatology eponyms. Our Dermatol Online. 2012;3:64-5.

2. Weismann K: J.H.S. Beau and his descriptions of transverse depressions on nails. Br J Dermatol. 1977;97:571-2.

3. Boulinguez S, Viraben R: Bywater's lesions. Dermatology. 2001;203:86

4. Herron MD, Florell S: What is your diagnosis? Bywaters lesions of rheumatoid vasculitis. Cutis. 2003;71:439,462,464.

5. Sayah A, English JC 3rd: Rheumatoid arthritis: a review of the cutaneous manifestations. J Am Acad Dermatol. 2005;53:191-9; quiz 210-2.

6. Bywaters EG: Peripheral vascular obstruction in rheumatoid arthritis and its relationships to other vascular lesions. Ann Rheum Dis. 1957;16:84-103.

7. Baran R, Kechijian P: Hutchinson's sign: a reappraisal. J Am Acad Dermatol. 1996;34:87-90.

8. van Ruth S, Toonstra J: Eponyms of Sir Jonathan Hutchinson. Int J Dermatol. 2008;47:754-8.

9. Jackson AD, Lawler SD: Pachyonychia congenita; a report of six cases in one family, with a note on linkage data. Ann Eugen. $1951 ; 16: 142-6$

10. Al Aboud A, Al Aboud K: Josef Jadassohn (1863-1936), Felix Lewandowsky (1879-1921), and their syndrome. Clin Cosmet Investig Dermatol. 2011;4:179-82.

11. Al Aboud K: Iso-Kikuchi syndrome; an overview. Our Dermatol Online. 2012;3:145-6.

12. Al Aboud A, Al Aboud K: Eponyms in dermatology literature linked to Japan. Clin Cosmet Investig Dermatol. 2012;5:15-21.

13. Chauhan S, D'Cruz S, Singh R, Sachdev A: Mees' lines. Lancet. 2008; 372:1410.

14. Wu YY, Chao TY: Mees' lines. Intern Med J. 2011;41:578. 15. Reynolds ES: An Account of the Epidemic Outbreak of Arsenical Poisoning occurring in Beer Drinkers in the North of England and the Midland Counties in 1900. Med Chir Trans. 1901;84:409-52.

16. Weiser JA, Rogers HD, Scher RK, Grossman ME: Signs of a „broken heart”: suspected Muehrcke lines after cardiac surgery. Arch Dermatol. 2007;143:815-6.

17. Novacek G: Plummer-Vinson syndrome. Orphanet J Rare Dis. 2006;1:36.

18. Anoop TM, Jabbar PK, Sujathan P: Plummer's nails. Onycholysis. N Z Med J. 2008;121:66-7.

19. Norton SA: Keratoderma with pseudo-Quincke's pulse. Cutis. $1998 ; 62: 135-6$. 
20. Terry R: White nails in hepatic cirrhosis. Lancet. 1954;266:7579.

21. Nia AM, Ederer S, Dahlem KM, Gassanov N, Er F: Terry's nails: a window to systemic diseases. Am J Med. 2011;124:602-4.
22. Haras B, Vulpoi F, Onose G: A case of nail-patella syndrome associated with thyrotoxicosis. J Med Life. 2012;5:126-9.

23. Turner JW: An hereditary arthrodysplasia associated with hereditary dystrophy of the nails. JAMA. 1933;100:882-4.

\begin{tabular}{|c|c|}
\hline Medical eponyms linked to nail & Remarks \\
\hline Bart-Pumphrey syndrome & $\begin{array}{l}\text { This syndrome is characterized by knuckle pads,leukonychia, palmoplanter } \\
\text { keratoderma and Sensorineural deafness. This syndrome is first described by Dr } \\
\text { Schwann, from Poland and appeared later in English literature by Robert S. Bart } \\
\text { (Dermatologist) and Robert E. Pumphrey (Otolaryngologist); both from USA [1]. }\end{array}$ \\
\hline Beau's lines & $\begin{array}{l}\text { Beau's lines are deep grooved lines in the nail plates [2]. The } \\
\text { duration of the insult may be estimated by the longitudinal width of the } \\
\text { damage. This condition of the nail was named by a French physician, } \\
\text { oseph Honoré Simon Beau (1806-1865), who first described it in } 1846 \text {. }\end{array}$ \\
\hline Bywaters' lesions & $\begin{array}{l}\text { Bywaters' lesions are cutaneous infarctions that occur in nail fold and } \\
\text { around the nailbeds in patients with rheumatoid arthritis. They are small, brown to } \\
\text { purpuric, painless lesions on the nail fold, nail edge, or digital pulp that are transient } \\
\text { and often go unnoticed [3-6]. Bywaters first described them in } 1957 \text {. }\end{array}$ \\
\hline Hutchinson's sign & $\begin{array}{l}\text { It is pigmentation of periungual tissue as a sign of melanoma }[7,8] \text {. It is named after, } \\
\text { Sir Jonathan Hutchinson (1828-1913). Periungual pigmentation is, also, present } \\
\text { in a variety of benign disorders, for which the term "Pseudo-Hutchinson's sign" is } \\
\text { suggested [7]. }\end{array}$ \\
\hline Jackson-Lawler syndrome & $\begin{array}{l}\text { It is a type of pachyonychia congenital (PC) - a disease that is characterized by } \\
\text { severe thickening of the nail due to massive nail hyperkeratosis. It is first described } \\
\text { by Jackson and Lawler in } 1951 \text { [9]. }\end{array}$ \\
\hline $\begin{array}{l}\text { Jadassohn-Lewandowsky } \\
\text { syndrome }\end{array}$ & $\begin{array}{l}\text { Another type of PC. It is named after two famous German dermatologists, Josef } \\
\text { Jadassohn (1863-1936) and his assistant, Felix Lewandowsky }(1879-1921) \text { [10]. }\end{array}$ \\
\hline Iso-Kikuchi syndrome & $\begin{array}{l}\text { It is a rare condition characterized by various forms of nail dysplasia } \\
\text { commonly involving the index fingers [11]. The first case report of this } \\
\text { condition was by Kamei, in 1966. Ryosuke Iso (1937-2009), a Japanese } \\
\text { plastic surgeon collected a series of patients and defined the clinical syndrome. } \\
\text { Reported later, by Ichiro Kikuchi, a contemporary Japanese dermatologist, who } \\
\text { coined the term 'congenital onychodysplasia of the index fingers' (COIF) [11,12]. }\end{array}$ \\
\hline Mees' lines & $\begin{array}{l}\text { Mees' lines or Aldrich-Mees' lines or Reynolds' lines are transverse } \\
\text { white bands on the nail plate laid down during periods of stress, or appear after an } \\
\text { episode of poisoning with arsenic, thallium or other heavy metals, and can also } \\
\text { appear if the subject is suffering from renal failure or other systemic insults [13-15]. } \\
\text { Although the phenomenon is named after Dutch physician R.A. Mees, who } \\
\text { described the abnormality in 1919, earlier descriptions of the same abnormality w } \\
\text { ere made by Englishman E.S. Reynolds in } 1901 \text { and by American C.J. Aldrich in } \\
\text { 1904. Mees' lines need to be distinguished from Muehrcke's lines, which represent } \\
\text { an abnormality of the vascular nail bed and disappear when the nail is compressed. }\end{array}$ \\
\hline Muehrcke's nails & $\begin{array}{l}\text { Muehrcke's nails, or Muehrcke's lines, or leukonychia striata, are } \\
\text { changes in the fingernail [16] that may be a sign of an underlying medical } \\
\text { disorder, most commonly hypoalbuminemia. White lines (leukonychia) } \\
\text { extend all the way across the nail and lie parallel to the lunula (half-moon). In } \\
\text { contrast to Beau's lines, they are not grooved. Muehrcke's lines were first } \\
\text { described by Robert C. Muehrcke (1921-2003), an American physician in } 1956 \text {. }\end{array}$ \\
\hline Paterson-Kelly syndrome & $\begin{array}{l}\text { Paterson-Kelly syndrome or Plummer-Vinson presents as a classical triad } \\
\text { of dysphagia, iron deficiencyAnemia and esophageal webs [17]. The } \\
\text { syndrome eponym has been frequently discussed. The most used name is } \\
\text { Plummer-Vinson syndrome,named after Henry Stanley Plummer (1874-1936) } \\
\text { and Porter Paisley Vinson (1890-1959) who were physicianson the staff of } \\
\text { the Mayo Clinic. Another term is Paterson-Kelly syndrome, named after, } \\
\text { Donald Ross Paterson (1863-1939) and Adam Brown-Kelly (1865-1941), both } \\
\text { British laryngologists, who published their findings independently in 1919. They } \\
\text { were the first to describe the characteristic clinical features of the syndrome [17]. }\end{array}$ \\
\hline
\end{tabular}




\begin{tabular}{|c|l|}
\hline Medical eponyms linked to nail & \multicolumn{1}{|c|}{ Remarks } \\
\hline Plummer's nail & $\begin{array}{l}\text { Onycholysis as a sign of hyperthyroidism. It is named after, Henry } \\
\text { Stanley Plummer, who was an American internist and endocrinologist [18]. }\end{array}$ \\
\hline Plummer-Vinson syndrome & See Paterson-Kelly syndrome, above. \\
\hline Quincke's pulse & $\begin{array}{l}\text { Alternate blanching and flushing of the nail bed due to pulsation of } \\
\text { subpapillary arteriolar and venous plexuses; seen in aortic insufficiency and } \\
\text { other conditions and occasionally in normal persons [19]. It is named after, } \\
\text { Heinrich Irenaeus Quincke (1842-1922), who was a German internist and surgeon. }\end{array}$ \\
\hline Terry's (white) nails & $\begin{array}{l}\text { Terry's (white) nails, is seen in association with systemic diseases like, } \\
\text { hepatic failure, cirrhosis, diabetes mellitus, congestive heart failure, } \\
\text { hyperthyroidism, and malnutrition. Terry's nails were first described } \\
\text { by the British physician Richard Terry, who investigated this nail-bed } \\
\text { abnormality in 82 of 100 consecutive patients with hepatic cirrhosis [20,21]. }\end{array}$ \\
\hline
\end{tabular}

Copyright by Khalid Al Aboud. This is an open access article distributed under the terms of the Creative Commons Attribution License, which permits unrestricted use, distribution, and reproduction in any medium, provided the original author and source are credited. 